\title{
The effects of dietary whey protein concentrate level on performance, selected intestinal tract and blood parameters, and thiobarbituric acid reactive substances in the liver and breast meat of broiler chickens
}

\author{
W. Szczurek ${ }^{1,4}$, B. Szymczyk ${ }^{1}$, A. Arczewska-Włosek¹, D. Józefiak² and M.N. Alloui1,3 \\ ${ }^{1}$ National Research Institute of Animal Production, Department of Animal Nutrition and Feed Science, 32-083 Balice, Poland \\ ${ }^{2}$ Poznań University of Life Sciences, Department of Animal Nutrition and Feed Management \\ Wołyńska 33, 60-637 Poznań, Poland \\ ${ }^{3}$ Currently a doctoral student at the National Research Institute of Animal Production, 32-083 Balice, Poland
}

KEY WORDS: broilers, whey protein concentrate, feeding, performance, blood, TBARS, intestinal pH, protein digestibility

Received: 11 March 2013

Revised: 25 September 2013

Accepted: 30 October 2013

\begin{abstract}
The aim of this study was to investigate the effect of two levels of whey protein concentrate (WPC, $80.35 \%$ protein, $5.86 \%$ lactose) added to diets and duration of these treatments on growth and slaughter value, haematological parameters involved in immune processes, oxidative status of liver and breast muscle, and selected indices of gut function of broilers. A total of 560 Ross 308 broilers were randomly allocated into 7 groups with 10 replicates of 8 chickens per replicate. The experiment lasted 42 days and was divided into 3 successive feeding phases. The control group was fed basal diets consisted of maize, wheat and soyabean meal ( $\mathrm{C}$ group). The other 6 groups received, for 7, 21 and 42 days basal diets with 8 or $32 \mathrm{~g} \cdot \mathrm{kg}^{-1}$ WPC added at the expense of soyabean meal (WL and WH groups, respectively). On day 42 group WH had a higher lymphocyte percentage $(P<0.05)$ compared to the control. The long-term (42 days) feeding with higher level of WPC significantly decreased the heterophile/lymphocyte ratio $(P<0.05$ vs $C)$. The number of erythrocytes on day 42 and the whole blood glucose on day 21 were significantly increased in WH birds than in controls. The concentration of serum total protein on both WPC levels was greater $(P<0.05)$ on day 21 compared with the $\mathrm{C}$ group. The reduction $(P<0.05)$ in liver thiobarbituric acid reactive substances (TBARS) and a tendency towards lower TBARS level in breast meat were observed in birds WH when fed for 42 days. Only higher dietary WPC amount provided for 42 days reduced the caecal and small intestinal $\mathrm{pH}$ values $(P<0.05$ vs $\mathrm{C})$. The ileal digestibility of crude protein was higher $(P<0.01)$ in birds fed with $32 \mathrm{~g}$ WPC during the first 21 days of life, compared to the $\mathrm{C}$ and WL treatments. The factorial ANOVA showed that on days 7, 21 and 42 the final body weight gain (BGW) and feed conversion ratio in broilers WL and $\mathrm{WH}$ were significantly better than in the $\mathrm{C}$ ones. Assessment of orthogonal contrasts revealed significantly higher $(P<0.05)$ final BWG in the WH broilers, compared to the WL dietary treatment; such effect was not observed in earlier feeding stages. Generally, carcass yield on both WPC dietary levels, and breast muscle percentage on WH treatment, were higher $(P<0.01$ and $P<0.05$, respectively) compare to the $C$ group. In conclusion, WPC added to a conventional diets for growing chickens exerts a growth-promoting action and at a dose of $32 \mathrm{~g} \cdot \mathrm{kg}^{-1}$ may induce desirable changes in bird's health and the intestinal tract metabolism.
\end{abstract}

\footnotetext{
${ }^{4}$ Corresponding author: e-mail: witold.szczurek@izoo.krakow.pl
} 


\section{Introduction}

Liquid whey from bovine milk and its derivatives obtained by spray drying (whole whey powder) or using membrane-based fractionation technologies contain a range of valuable compounds. Among them, lactose and whey proteins (WP) are the major constituents. Whey proteins are of special importance. These are represented mainly by $\beta$-lactoglobulin, $\alpha$-lactalbumin, immunoglobulins, bovine serum albumin, lactoferrin and lactoperoxidase. Their concentrations vary depending, among other factors, on breed, feeding system and season (Brodziak et al., 2012). Beside highly pure but costly isolates (above $90 \%$ total protein w/w), the most common and affordable form of native whey proteins are concentrates (WPC) containing up to $89 \%$ protein and at least 4\% lactose (http://www.geafiltration.com/applications). WP belongs to a class of proteins with an exceptionally high biological value and very rich in lysine and leucine, with considerable contents of methionine plus cystine. The last two play a key role in cellular antioxidant status, serving as precursors for glutathione (Shoveller et al., 2005). In addition to their excellent nutritional value, WP possesses health-related properties with regard to immune enhancing effects, gastrointestinal hormone secretion, antimicrobial and antiviral actions, and such other metabolic functions as satiety response and muscle anabolism (Madureira et al., 2007).

The use of whey derivatives in animal nutrition is one of the major pathways of their utilization. Many positive observations pertaining to the application of whey products high in lactose (dried whey) in weanling pig diets, and WPCs in calf milk replacers can be found in the literature (http://www.euromilk. org/ewpa/publications). WPCs are undoubtedly an excellent source of amino acids for young birds and other fast-growing monogastric animals. They are not, however, a competitively priced source of dietary protein for the animal feed industry. Recent market data show that whey protein is $7-8$ times more expensive than protein from regular soyabean meal (www.dairyglobalnutrition.org). For this reason, in practical poultry diets WPCs can be used in comparatively small amounts as a biologically active ingredient that may provide physiological benefits rather than as a basic protein-supplying feedstuff.

Another factor potentially affecting the use of WPCs in poultry feeds is the presence of lactose. Birds, unlike mammals, are unable to efficiently digest this disaccharide and about half of ingested lactose passes into the lower intestinal tract (Atkinson et al., 1957). The results of some studies have shown the ability of chicken gut anaerobic microbiota to convert lactose to short-chain organic acids, especially lactate and propionate (Rehman et al., 2009). A lower $\mathrm{pH}$ of the digesta resulting from lactose fermentation may have a positive impact on intestinal histomorphology and/or on the colonization of beneficial microflora in the gastrointestinal tract when administered at both very high $(10 \%)$ or moderate (2.8\%) levels (Tellez et al., 1993; Samli et al., 2007). Conflicting data exist, however, about the effects of dietary lactose on chicken growth performance. Recently, Józefiak et al. (2008) demonstrated that $2 \mathrm{~g} \cdot \mathrm{kg}^{-1}$ diet of purified lactose significantly decreased the body weight gain of broilers grown to market age. In contrast, Douglas et al. (2003) found that addition of 20 or $40 \mathrm{~g}$ lactose (pure form) resulted in numerical increases in weight gain of young chickens (1-20 days of age), whereas only the level of $60 \mathrm{~g} \cdot \mathrm{kg}^{-1}$ decreased their growth and feed efficiency, but caused more loose (watery) excreta.

Except for the report of Awano (2004) concerning the effects of a high $\left(180 \mathrm{~g} \cdot \mathrm{kg}^{-1}\right)$ dietary level of WPC fed for 11 days, we have found no information on whether adding it to diets could support the desired performance outcomes in modern broiler chickens. With regard to the high cost of this product, no attention has been paid to the effects of low levels and different durations of feeding WPCs to broilers when reared to a typical slaughter end point (42-43 days of age). In our study the assumption was made that the favourable bio-physiological properties of whey proteins (and lactose) would be reflected in enhanced intestinal tract metabolic processes, better overall health status, and improved productivity of chickens. It was also hypothesized that dietary WPC provided during the initial periods of feeding may influence later growth and slaughter performance. The objective of this experiment was to investigate the effect of the amount of whey protein concentrate included in diets and duration of feeding chickens with WPC-containing diets on growth and slaughter value, haematological parameters involved in immune processes, oxidative status of liver and breast muscle, and selected indices of gut function of the birds.

\section{Material and methods}

\section{WPC preparation used}

A commercial bovine whey protein concentrate (WPC) was purchased from Mazovian Dairy Cooperative 'Ostrowia' (Poland). Before being used in the diets, the composition of the preparation was analysed. The WPC contained (in \% of air-dry matter): 80.35 crude protein $(\mathrm{N} \times 6.38), 8.02$ lysine, 1.79 
methionine, 1.99 cystine, 5.93 threonine, 2.20 arginine, 4.93 isoleucine, 9.15 leucine, 4.81 valine, 1.94 histidine, 2.74 phenylalanine, and 5.86 lactose, 6.05 crude fat and 2.23 crude ash.

\section{Birds, housing and feeding}

All experimental procedures were conducted according to the Guidelines for Animal Care and Treatment of the European Union, and were reviewed and approved by the Local Ethics Committee for Animal Experimentation. A total of 560 feather-sexed Ross 308 broiler chickens was included in the study. The average body weight of one-day-old chicks was $41.2 \pm 0.6 \mathrm{~g}$. To distinguish a bird's sex in the course of the first 3-4 weeks of the experiment, male chickens were marked on their head with a water-resistant felt-tip pen. Marks were refreshed on days 7, 14 and 21 of life. When necessary, selection of males and females at the end of experiment was based on secondary sex characteristics. The birds were raised in battery wire-floor cages and had unlimited access to feed and water. Temperature was maintained at $32^{\circ} \mathrm{C}$ during days $1-5$ and then gradually reduced to $22^{\circ} \mathrm{C}$ until the end of rearing. The lighting cycle was set to provide
$18 \mathrm{~h}$ light and $6 \mathrm{~h}$ dark per day. All birds were fed on mash feeds including: prestarter type diets from day 1 to 7 , starter type diets from day 8 to 21 , and grower type diets from day 22 to 42 (Table 1). Apart from anticoccidials, the diets did not contain any specific additives (antioxidants, enzymes, $\mathrm{pH}$ control agents, etc.). During the experiment the chickens were inspected twice daily for general health status and mortality.

\section{Experimental layout and treatments}

The experiment was performed in a randomized block arrangement with 10 replicate cages of 8 chickens (4 males and 4 females) assigned to each dietary group. An augmented factorial design, WPC dietary level by period when chickens were provided WPC-containing diets $(2 \times 3)$ plus one control group, was used (Lentner and Bishop, 1993). Effect of sex was also considered when analysing post-slaughter variables $(2 \times 3 \times 2)$. Seven dietary combinations were tested (Table 2 ). The control group was fed basal diets only. The other six treatment groups of chickens received diets with WPC powder added in amounts of 8 or $32 \mathrm{~g} \cdot \mathrm{kg}^{-1}$. The WPC additions were made to the basal diets at the expense of soyabean meal (SBM;

Table 1. Composition of the experimental diets, $\mathrm{g} \cdot \mathrm{kg}^{-1}$

\begin{tabular}{|c|c|c|c|c|c|c|c|c|c|}
\hline \multirow[b]{2}{*}{ Indices } & \multicolumn{3}{|c|}{ Prestarter } & \multicolumn{3}{|l|}{ Starter } & \multicolumn{3}{|l|}{ Grower } \\
\hline & $\begin{array}{l}\text { basal } \\
\text { (control) }\end{array}$ & $\begin{array}{l}8 \mathrm{~g} \\
W P C^{1}\end{array}$ & $\begin{array}{l}32 \mathrm{~g} \\
\text { WPC }\end{array}$ & $\begin{array}{l}\text { basal } \\
\text { (control) }\end{array}$ & $\begin{array}{l}8 \mathrm{~g} \\
\text { WPC }\end{array}$ & $\begin{array}{l}32 \mathrm{~g} \\
\text { WPC }\end{array}$ & $\begin{array}{l}\text { basal } \\
\text { (control) }\end{array}$ & $\begin{array}{l}8 \mathrm{~g} \\
\text { WPC }\end{array}$ & $\begin{array}{l}32 \mathrm{~g} \\
\text { WPC }\end{array}$ \\
\hline \multicolumn{10}{|l|}{ Ingredients } \\
\hline maize & 399.8 & 410.3 & 439.5 & 405.2 & 415.7 & 444.8 & 383.4 & 392.9 & 421.9 \\
\hline wheat & 140.0 & 140.0 & 140.0 & 170.0 & 170.0 & 170.0 & 230.0 & 230.0 & 230.0 \\
\hline soyabean meal & 395.0 & 381.0 & 339.0 & 350.0 & 336.0 & 294.0 & 300.0 & 286.0 & 244.0 \\
\hline rapeseed oil & 20.0 & 16.0 & 6.0 & 30.0 & 26.0 & 16.0 & 45.0 & 42.0 & 32.0 \\
\hline $\mathrm{Ca}\left(\mathrm{H}_{2} \mathrm{PO}_{4}\right)_{2}$ & 18.0 & 18.0 & 18.0 & 18.0 & 18.0 & 18.0 & 16.0 & 16.0 & 16.0 \\
\hline limestone & 16.0 & 16.0 & 16.0 & 16.0 & 16.0 & 16.0 & 15.0 & 15.0 & 15.0 \\
\hline $\mathrm{NaCl}$ & 3.0 & 3.0 & 3.0 & 3.0 & 3.0 & 3.0 & 3.0 & 3.0 & 3.0 \\
\hline premix $^{2,3}$ & $5.0^{2}$ & $5.0^{2}$ & $5.0^{2}$ & $5.0^{2}$ & $5.0^{2}$ & $5.0^{2}$ & $5.0^{3}$ & $5.0^{3}$ & $5.0^{3}$ \\
\hline L-lysine & 1.6 & 1.2 & 0.2 & 1.3 & 0.9 & - & 1.2 & 0.8 & - \\
\hline DL-met & 1.6 & 1.5 & 1.3 & 1.5 & 1.4 & 1.2 & 1.4 & 1.3 & 1.1 \\
\hline WPC & - & 8.0 & 32.0 & - & 8.0 & 32.0 & - & 8.0 & 32.0 \\
\hline \multicolumn{10}{|c|}{ Calculated composition ${ }^{4}$} \\
\hline $\mathrm{ME}, \mathrm{MJ} \cdot \mathrm{kg}^{-1}$ & 11.72 & 11.72 & 11.73 & 12.12 & 12.11 & 12.13 & 12.71 & 12.70 & 12.70 \\
\hline crude protein & 236 & 237 & 239 & 219 & 221 & 223 & 201 & 203 & 205 \\
\hline lysine & 13.5 & 13.5 & 13.6 & 12.2 & 12.1 & 12.3 & 10.9 & 10.9 & 11.1 \\
\hline methionine & 5.1 & 5.1 & 5.1 & 4.8 & 4.8 & 4.8 & 4.5 & 4.5 & 4.5 \\
\hline met + cys & 9.0 & 9.0 & 9.3 & 8.5 & 8.5 & 8.8 & 7.9 & 7.9 & 8.3 \\
\hline threonine & 8.7 & 9.0 & 9.7 & 8.0 & 8.3 & 9.1 & 7.3 & 7.6 & 8.4 \\
\hline tryptophan & 2.5 & 2.5 & 2.7 & 2.3 & 2.3 & 2.5 & 2.1 & 2.1 & 2.3 \\
\hline $\mathrm{Ca}$ & 11.3 & 11.3 & 11.4 & 11.2 & 11.2 & 11.3 & 10.3 & 10.3 & 10.4 \\
\hline $\mathrm{P}$ available & 5.4 & 5.4 & 5.5 & 5.3 & 5.3 & 5.4 & 4.8 & 4.8 & 4.9 \\
\hline
\end{tabular}

${ }^{1}$ WPC - whey protein concentrate; ${ }^{2,3}$ vitamin-trace mineral premix provided per kg of diet:IU: ${ }^{2}$ vit.A13500; vit. D 3600; mg: vit. E45; vit. $K_{3} ;$ vit. $B_{1} 3.25$; vit. $B_{2} 7.5$; vit. $B_{6} 5$; vit. $B_{12} 0.03$; biotin 0.15 ; folic acid 1.5 ; nicotinic acid 45 ; calcium pantothenate 15 ; choline chloride $600 ; \mathrm{Fe} 67.5 ; \mathrm{Zn} \mathrm{75;} \mathrm{Mn} 100 ; \mathrm{Cu}$ 17.5 ; I 1; Se 0.28; Co 0.4; coccidiostat (diclazuril) 1; ${ }^{2}$ IU: vit. A 12000; vit. D 3250; mg: vit. E 40; vit. K2.25; vit. $B_{1} 2$; vit. $B_{2} 7.25$; vit. $B_{6} 4.25$; vit. $B_{12} 0.03$; biotin 0.1 ; folic acid 1; nicotinic acid 40; calcium pantothenate 12; choline chloride 450; Fe 65; Zn 65; Mn 100; Cu 15; I 0.8; Se 0.25; Co 0.4; coccidiostat (semduramycin) $25 ;{ }^{4}$ calculated on the basis of chemical analysis of feed ingredients; energy value, including that for WPC $\left(15.47 \mathrm{MJ} \cdot \mathrm{kg}^{-1}\right)$ - using formulas of The European Table of Energy Values for Poultry Feedstuffs (1989). $3^{\text {rd }}$ Edition, WPSA, Wageningen 
$46.1 \% \mathrm{CP}$ in air-dry matter) on a crude protein content basis, thus 14 or $56 \mathrm{~g} \cdot \mathrm{kg}^{-1} \mathrm{SBM}$, respectively, were replaced by WPC. Levels of supplemental the basal diets at the expense of soyabean meal lysine and methionine were adjusted with L-lys $\mathrm{HCl}$ (79\%) and DL-met (99\%), respectively, to maintain similar concentrations of these amino acids and cystine within diets for each phase. For threonine this was not possible. The metabolizable energy was adjusted by decreasing amounts of the vegetable oil. Feeding the WPC-containing diets was initiated on day 1 of age (Table 2) and was continued for 7 days of the prestarter phase (treatments denoted as 8WPC_7 and 32WPC_7), for 21 days of the prestarter and starter phases (treatments 8WPC 21 and 32WPC 21), or for the entire period of the experiment (treatments 8WPC_42 and 32WPC 42). After termination of short-term feeding periods on WPC diets ( 7 or 21 days) the chickens were switched to the respective basal diet. The original experimental design comprised the two or three aforementioned factors, however, only the final growth performance and post-slaughter characteristics data were collected in a manner that made the use of full factorial analysis of variance possible.

Table 2. Scheme of the experimental design, data collection and determination of parameters

\begin{tabular}{|c|c|c|c|}
\hline \multirow[b]{2}{*}{$\begin{array}{l}\text { Group/dietary } \\
\text { treatment }\end{array}$} & \multicolumn{3}{|c|}{ Days (feeding phase) / diet } \\
\hline & $\begin{array}{l}1-7 \\
\text { prestarter }\end{array}$ & $\begin{array}{l}8-21 \\
\text { starter }\end{array}$ & $\begin{array}{l}22-42 \\
\text { grower }\end{array}$ \\
\hline 1 Control & basal $^{2}$ & basal $2,3,4,5,6$ & basal $2,3,4,5,6,7,8$ \\
\hline 2 8WPC_71 & $8 \mathrm{~g} \mathrm{WPC}^{2}$ & basal $^{2}$ & basal 2,7 \\
\hline 3 8WPC_21 & $8 \mathrm{~g} \mathrm{WPC}^{2}$ & $8 \mathrm{~g} \mathrm{WPC} 2,3,4,5,6$ & basal 1,6 \\
\hline 4 8WPC_42 & $8 \mathrm{~g} \mathrm{WPC}^{2}$ & $8 \mathrm{~g} \mathrm{WPC}^{2}$ & $8 \mathrm{~g} \mathrm{WPC} 2,3,4,5,6,7,8$ \\
\hline 5 32WPC_7 & $32 \mathrm{~g} \mathrm{WPC}^{2}$ & basal $^{2}$ & basal $^{1,6}$ \\
\hline 6 32WPC_21 & $32 \mathrm{~g} \mathrm{WPC}^{2}$ & $32 \mathrm{~g} \mathrm{WPC} 2,3,4,5,6$ & 6 basal 1,6 \\
\hline 7 32WPC_42 & $32 \mathrm{~g} \mathrm{WPC}^{2}$ & $32 \mathrm{~g} \mathrm{WPC}^{1}$ & 32 g WPC $2,3,4,5,6,7,8$ \\
\hline
\end{tabular}

${ }^{1}$ WPC - whey protein concentrate; $23,4,5,6,7,7,8$ parameters monitored or etermined: ${ }^{2}$ body weight, feed intake, death and culling losses; ${ }^{3} \mathrm{pH}$ of caecal contents and the small intestinal digesta, weight of the small intestine; ${ }^{4}$ selected blood indices; ${ }^{5}$ thiobarbituric acid reactive substances (TBARS) values of fresh liver tissue; ${ }^{6}$ apparent ileal digestibility of crude protein in basal diet without WPC (day 26 of age); ${ }^{7}$ carcass traits and selected organ weights; ${ }^{8}$ TBARS values of breast meat after 3-month storage at $-20^{\circ} \mathrm{C}$

\section{Measurements, sampling, and calculations}

The chickens were weighed by cage on day 1 and at the ages of 7,21 and 42 days after $4 \mathrm{~h}$ feed deprivation. Feed intake (FI) was recorded on a replicate (cage) basis. Body weight gains (BWG) were calculated for the entire 42-day period of rearing and for the three sub-periods. Feed conversion ratio (FCR) values were corrected for the weight of dead and culled birds. Mean BWG, FI and FCR were used to evaluate growth performance. On day 21 of life, 6 birds (sex ratio 1:1) per treatment in groups 8WPC_21 and 32WPC_21, and the control group were randomly chosen, labeled, and weighed. Blood samples of four mixed-sex chickens (per six selected) were taken from the wing vein and collected into test tubes not treated with anticoagulant or pretreated with EDTA. At the same time, a drop of whole blood was rapidly taken and placed on a blood glucose test strip and the glucose value was measured with a portable MediSense Precision QID meter (Abbott Diabetes Care Ltd., UK). The blood in tubes without anticoagulant was allowed to clot at $37^{\circ} \mathrm{C}$ for $30 \mathrm{~min}$., set at $4^{\circ} \mathrm{C}$ overnight, and centrifuged $(3000 \mathrm{~g}, 10 \mathrm{~min})$ to obtain serum for subsequent determination of total protein content. Whole blood in the EDTA-pretreated tubes was used for some haematological analyses. After blood collection, all selected birds were killed by cervical dislocation. Immediately after slaughter, the livers of 4 mixed-sex chickens per group were excised and 2-thiobarbituric acid reactive substances (TBARS) were measured in them. The caeca were removed and the $\mathrm{pH}$ of their contents was determined on-site by direct insertion of the electrode tip into the caecal lumen. Digesta from the whole small intestine tract of each bird were collected, placed into plastic containers and stirred for $1 \mathrm{~min}$ before $\mathrm{pH}$ determination. All $\mathrm{pH}$ measurements were taken in duplicate on a digital pH-meter (CyberScan pH 510, Eutech Instruments, Singapore). Moreover, the empty small intestines were cleaned, dried with blotting paper and weighed. The intestinal weight was expressed relative to $100 \mathrm{~g}$ live body weight (LBW).

To determine the apparent ileal digestibility of crude protein (AIDCP) in the grower type diet without WPC, after termination of a 3-week period of feeding birds with WPC-fortified prestarter/starter diets, a digestion trial was carried out based on ad libitum access to the feed and the slaughter technique of digesta collection. On day 21, one replicate cage ( 8 chickens) per control and treatment groups denoted as 8WPC_21 and 32WPC_21 were randomly selected and fed the basal grower diet mixed with chromic oxide $\left(5 \mathrm{~g} \cdot \mathrm{kg}^{-1}\right)$ for 5 days prior to slaughter. On 26 day of age the chickens were euthanized and the contents of the lower half of the ileum were flushed with deionized water. Digesta from 2 mixed-sex birds were pooled and freeze-dried. Calculation of the AIDCP coefficients was based on the proportion of $\mathrm{N} \times 6.25$ to $\mathrm{Cr}$ contents of the diet and ileal digesta. 
After weighing chickens on day 42, three males and three females were selected at random from each of the following groups: control, 8WPC_42 and 32WPC_42. Blood samples were collected and processed, as described above, from 4 mixed-sex chickens per group. Afterwards, all selected birds were sacrificed and their livers immediately excised for TBARS determination. The caeca and small intestines were also quickly removed and subjected to the above-described measurement procedures $(\mathrm{pH}$ determination, small intestine weight).

At the end of the experiment (day 43), twelve birds (sex ratio 1:1, with LBW close to the group average) were chosen from each dietary group and used for slaughter analysis. All of the birds were fasted $12 \mathrm{~h}$, weighed and killed by cervical dislocation. During evisceration, the weights of the liver and spleen were recorded. The carcasses with edible giblets were chilled overnight at $4^{\circ} \mathrm{C}$, weighed and then dissected to measure the mass of skinless breast muscles and abdominal fat. The carcass percentage yield and the relative weight of liver and spleen were calculated on the basis of LBW. The breast meat yield and abdominal fat deposition were calculated relative to the cold carcass mass.

\section{Analytical methods}

The concentrations of proximate nutrients in dietary feed and WPC powder, and of dry matter and crude protein $(\mathrm{N} \times 6.25)$ in the basal grower diet and lyophilized digesta were analysed according to AOAC (2000) procedures. The lactose content of WPC was determined using the standard LuffSchoorl titration method. Amino acid concentrations in the WPC sample were determined by HPLC (AOAC, 2000; method 982.30 E) using an AAA 400 (Ingos Ltd., Czech Republic) analyzer. The chromium contents in diet and ileal digesta samples were measured by the method of Saha and Gilbreath (1991) with an Avanta Sigma (GBC Ltd., Australia) atomic absorption spectrophotometer after wet mineralization of the samples in a nitric/perchloric acid mixture. The extent of lipid oxidation in both fresh liver tissue and breast muscle after storage at $-20^{\circ} \mathrm{C}$ for 90 days was determined as TBARS according to the extraction method of Salih described by Pikul et al. (1989). TBARS were expressed as milligrams of malondialdehyde (MDA) per kilogram of tissue. All chemical analyses were performed in duplicate.

Haematocrit values were determined using microhaematocrit capillary tubes by centrifuging at $6000 \mathrm{~g}$ for $5 \mathrm{~min}$, and haemoglobin was estimated by Drabkin's cyanmet haemoglobin method. Serum total protein determination was based on the biuret colour reaction using the Pointe Scientific Total Protein Reagent Set (T7528-100, Pointe Scientific Poland Ltd.). Red (RBC) and white (WBC) blood cell counts were determined by conventional laboratory methods in a Bürker haemocytometer. For RBC enumeration, the blood was diluted in Hayem solution (1/200) and WBC counts were estimated in blood haemolysed with Türk solution (in a $1 / 20$ dilution). Blood smears stained with a Hemacolor ${ }^{\circledR}$ Rapid Staining Kit no. 111661 (Merck Millipore, Poland) were prepared to microscopically enumerate lymphocytes (L) and heterophiles $(\mathrm{H})$, and the $\mathrm{H}: \mathrm{L}$ ratio was calculated. Except for whole blood glucose, each blood data point was the average of duplicate measurements of each sample.

\section{Statistical analysis}

The replicate cage served as the experimental unit for growth performance indices, and individual birds of both sexes were the experimental units for statistical analysis of post-slaughter and bio-physiological data. Statistical evaluation of all of the results was conducted with the Statistica ${ }^{\circledR}$ ver. 6 package (StatSoft Inc. Tulsa, OK, USA). Data on growth (total $n=70$ ) and slaughter (total $n=84$ ) performances were analysed by factorial analysis of variance with an isolated control group. When analysing production data, the effect of sex was not included in the model since these results were cage means. In this design, for comparing individual treatments or several treatment means with an isolated control group, some pre-planned orthogonal contrasts were tested for significance by Fisher's test. The data for mixed-sex chickens resulting from their intestinal tract measurements (total $n=18$ ), AIDCP determination (total $\mathrm{n}=12$ ), and TBARS and blood analyses (total $\mathrm{n}=12$ ) were subjected to one-way analysis of variance with WPC dietary level as the explanatory variable. If the probability value of F-tests was $<0.1$, differences among main effect means (2(3)-way ANOVA) and treatment means (1-way ANOVA) were determined with the Tukey's HSD post-test. Differences between means were considered significant when $P<0.05$.

\section{Results}

\section{Growth performance}

Mortality defined as live culling and death rate throughout the rearing period was moderate $(2.5 \%$ on average) and was not associated with any particular treatment (Table 3). When the average data across all of the feeding period lengths were com- 
Table 3. Effect of dietary WPC level and period of administration in the feed (days of life) on growth performance of chickens reared for 42 days

\begin{tabular}{|c|c|c|c|c|c|}
\hline Group $^{1}$ & $\begin{array}{l}\text { Body weight } \\
\text { gain, } \\
\mathrm{kg}\end{array}$ & $\begin{array}{l}\text { Feed } \\
\text { intake, } \\
\mathrm{kg} \cdot \text { bird }^{-1}\end{array}$ & $\begin{array}{l}\text { Feed } \\
\text { conversion, } \\
\mathrm{kg} \cdot \mathrm{kg}^{-1} \mathrm{BWG}\end{array}$ & $\begin{array}{l}\text { Mortality }^{2} \\
\text { rate }(d+c) \text {, } \\
\%\end{array}$ & No. of cases d/c \\
\hline \multicolumn{6}{|l|}{ Treatment means } \\
\hline 1 Control & 1.96 & 3.77 & 1.92 & 2.50 & $1 / 1$ \\
\hline 2 8WPC_7 & 2.00 & 3.60 & 1.80 & 1.25 & $0 / 1$ \\
\hline 3 8WPC_21 & 2.10 & 3.76 & 1.79 & 3.75 & $1 / 2$ \\
\hline 4 8WPC_42 & 2.13 & 3.73 & 1.76 & 1.25 & $1 / 0$ \\
\hline 5 32WPC_7 & 2.03 & 3.59 & 1.77 & 2.50 & $0 / 2$ \\
\hline 6 32WPC_21 & 2.09 & 3.59 & 1.72 & 3.75 & $1 / 2$ \\
\hline 7 32WPC_42 & 2.21 & 3.76 & 1.70 & 2.50 & $1 / 1$ \\
\hline Pooled SEM & 0.01 & 0.02 & 0.01 & 0.60 & \\
\hline \multicolumn{6}{|c|}{ Main effect means and significance ${ }^{3}$} \\
\hline \multicolumn{6}{|c|}{ Dietary level of WPC } \\
\hline $8, \mathrm{~g} \cdot \mathrm{kg}^{-1}$ & 2.08 & 3.69 & $1.78^{\mathrm{a}}$ & 2.08 & $2 / 3$ \\
\hline $32, \mathrm{~g} \cdot \mathrm{kg}^{-1}$ & 2.11 & 3.65 & $1.73^{b}$ & 2.92 & $2 / 5$ \\
\hline$P$-value & 0.152 & 0.208 & 0.048 & 0.535 & \\
\hline \multicolumn{6}{|c|}{ Duration of feeding diets with WPC } \\
\hline $1-7$ days & $2.02^{\mathrm{a}}$ & $3.59^{\mathrm{a}}$ & 1.79 & 1.87 & $0 / 3$ \\
\hline $1-21$ days & $2.09^{b}$ & $3.68^{b}$ & 1.76 & 3.75 & $2 / 4$ \\
\hline $1-42$ days & $2.17^{c}$ & $3.75^{c}$ & 1.73 & 1.87 & $2 / 1$ \\
\hline$P$-value & $<0.0001$ & 0.032 & 0.161 & 0.421 & \\
\hline \multicolumn{6}{|l|}{ Interaction } \\
\hline$P$-value & 0.179 & 0.154 & 0.781 & 0.907 & \\
\hline \multicolumn{6}{|l|}{ Contrasts ${ }^{4}$} \\
\hline$C 1=1$ vs $2+3+4$ & $* * *$ & ns & $* * *$ & ns & \\
\hline$C 2=1$ vs $5+6+7$ & $* * *$ & $*$ & $* * *$ & ns & \\
\hline$C 3=1$ vs 2 & ns & ** & $* *$ & ns & \\
\hline$C 4=1$ vs 3 & $* * *$ & ns & $* *$ & ns & \\
\hline$C 5=1$ vs 5 & ns & $* *$ & $* *$ & ns & \\
\hline$C 6=1$ vs 6 & $* *$ & $* *$ & $* * *$ & ns & \\
\hline$C 7=2$ vs 5 & ns & ns & ns & ns & \\
\hline$C 8=3$ vs 6 & ns & $* *$ & ns & ns & \\
\hline$C 9=4$ vs 7 & $*$ & ns & ns & ns & \\
\hline
\end{tabular}

${ }^{1}$ dietary treatment abbreviations - see Table $2 ;{ }^{2}$ includes birds found dead (d) and that were culled (c) due to injuries to wings and leg abnormalities; ${ }^{3}$ for main effects, values within a column with different letters are significantly different at $P<0.05 ;{ }^{4}$ significance: ns $-P>0.05,{ }^{*}-P<0.05$, ${ }^{* *}-P<0.01,{ }^{* * *}-P<0.001$

pared, only a numerical difference in the 42-day BWG was found between the levels of dietary WPC inclusion $\left(32>8 \mathrm{~g} \cdot \mathrm{kg}^{-1} \mathrm{diet}\right)$. Assessment of orthogonal contrasts revealed, however, a higher $(P<0.05)$ BWG on $32 \mathrm{~g} \mathrm{WPC}$ compared with the 8 $\mathrm{g}$ WPC dietary treatment, when both were supplied over the entire experimental period (contrast C9). Independently of the duration of feeding WPC to birds, the overall FCR on diets with the addition of $32 \mathrm{~g} \cdot \mathrm{kg}^{-1}$ was significantly better $(P<0.05)$. In general, with increasing time on WPC-fortified feeds (both WPC dietary levels) a significant increase in final BWG of chickens was observed $(P<0.05)$, accompanied by elevated feed consumption $(P<0.05)$. Nonetheless, there were no two-way interactions for BWG, FI, FCR, or mortality $(P>0.1)$. In broilers receiving the control diets, the indices of final productive performance
(BWG, FCR) were significantly $(P<0.001)$ poorer than in birds fed WPC-containing diets (contrasts $\mathrm{C} 1$ and $\mathrm{C} 2$ ). Also, partial weight gains of control chickens in consecutive sub-periods of feeding were numerically or significantly lower than those of treatment groups (the relevant data are presented in Figure 1). A detailed analysis of contrasts showed that the presence of WPC, at both rates of inclusion, in diets fed up to 21 days of age yielded a significantly higher BWG and better FCR at 42 days in comparison with the respective values for the control diets with no preparation added (C4 and C6). Broilers belonging to the 8WPC 7 and 32WPC_ 7 treatments consumed overall significantly $(P<0.01)$ less feed than birds from the control group, but this did not negatively affect their BWG at the end of the experiment and gave better values of FCR (contrasts $\mathrm{C} 3$ and C5; Table 3). 


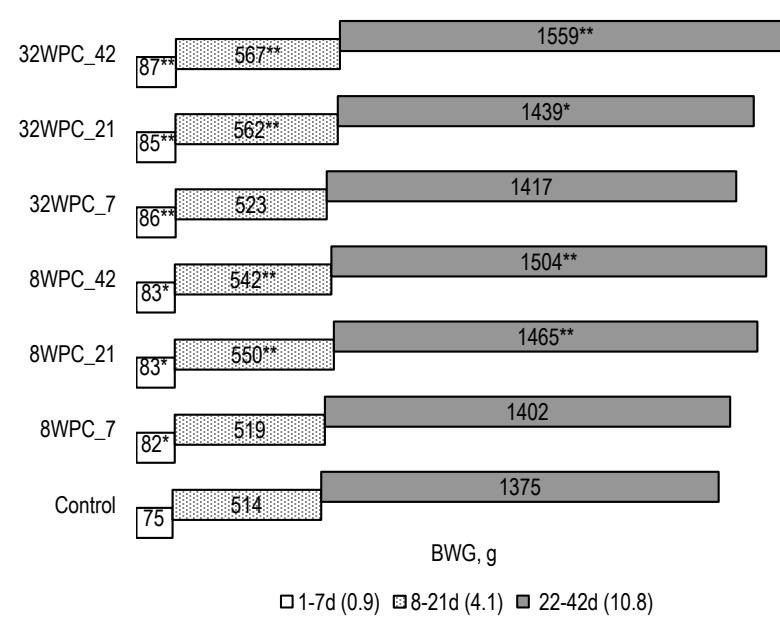

Figure 1. Differences between the control and experimental groups of chickens in body weight gains (BWG) during consecutive feeding phases. Means denoted by asterisks are significantly different from the control values: * $P<0.05$; ${ }^{* *} P<0.01$ (Tukey's HSD test). Pooled SEM for each set of data is given in parentheses

\section{Post-slaughter indices}

As expected, females had higher relative abdominal fat deposition than males (Table 4), and it is not surprising that a higher breast muscle percentage was found in females (http://en.aviagen. com/...Ross308BroilerPerfObj2012R1.pdf). The WPC dietary level by sex, feeding duration by sex, or WPC dietary level by feeding duration by sex interactions were not significant $(P>0.1)$ for any of the calculated carcass traits or relative organ weight. In general, a significant main effect for dietary level of WPC was found for breast meat yield $(P=0.043)$, while differences in other parameters were insignificant. The overall effect of feeding duration with the WPC-containing diets was seen only for breast meat yield and relative spleen weight. Their value increased $(P<0.05)$ as feeding duration increased from 1-7 to 1-42 days. The average carcass yields on both levels of WPC dietary supplementation (across feeding duration) were significantly better compared with the control group (contrasts $\mathrm{C} 1$ and $\mathrm{C} 2 ; P<0.01$ ). These general responses were also confirmed in chickens from treatment groups of medium (3 weeks) length of feeding diets with both WPC supplements (contrasts $\mathrm{C} 4$ and $\mathrm{C} 6 ; P<0.05$ ). Only the $32 \mathrm{~g} \cdot \mathrm{kg}^{-1}$ dietary level of WPC yielded an overall breast muscle percentage (across feeding duration) that was significantly higher than the control value $(\mathrm{C} 2 ; P<0.05)$, and the same was true with this level of WPC inclusion in diets fed solely through the 21-day period (C6; $P<0.05$; Table 4).
Table 4. Effect of dietary WPC level and period of administration in the feed (days of life) on carcass traits and the relative weight of selected organs

\begin{tabular}{|c|c|c|c|c|c|}
\hline \multirow[t]{2}{*}{ Group ${ }^{1}$} & \multirow[t]{2}{*}{$\begin{array}{l}\text { Carcass } \\
\text { yield, \% }\end{array}$} & $\begin{array}{l}\text { Breast } \\
\text { meat } \\
\text { yield }\end{array}$ & $\begin{array}{l}\text { Abdo- } \\
\text { minal } \\
\text { fat }\end{array}$ & \multirow{2}{*}{$\frac{\text { Liver }}{\% \text { of } L}$} & \multirow{2}{*}{$\frac{\text { Spleen }}{\text { LBW }^{2}}$} \\
\hline & & \multicolumn{2}{|c|}{$\begin{array}{l}\% \text { of carcass } \\
\text { weight }\end{array}$} & & \\
\hline \multicolumn{6}{|l|}{ Treatment means } \\
\hline 1 Control & 75.8 & 23.8 & 1.62 & 2.084 & 0.184 \\
\hline 2 8WPC_7 & 77.1 & 23.8 & 1.72 & 2.160 & 0.189 \\
\hline 3 8WPC_21 & 77.2 & 23.9 & 1.40 & 2.112 & 0.196 \\
\hline 4 8WPC_42 & 77.7 & 25.9 & 1.50 & 1.976 & 0.214 \\
\hline 5 32WPC_7 & 76.7 & 24.2 & 1.36 & 1.981 & 0.181 \\
\hline 6 32WPC_21 & 77.4 & 25.8 & 1.33 & 1.975 & 0.200 \\
\hline 7 32WPC_42 & 77.8 & 26.2 & 1.62 & 2.054 & 0.221 \\
\hline Pooled SEM & 0.18 & 0.23 & 0.05 & 0.025 & 0.005 \\
\hline \multirow{2}{*}{\multicolumn{6}{|c|}{$\begin{array}{l}\text { Main effect means and significance }{ }^{3} \\
\text { Dietary level of WPC }\end{array}$}} \\
\hline & & & & & \\
\hline $8, \mathrm{~g} \cdot \mathrm{kg}^{-1}$ & 77.3 & $24.5^{\mathrm{a}}$ & 1.54 & 2.083 & 0.199 \\
\hline $32, \mathrm{~g} \cdot \mathrm{kg}^{-1}$ & 77.3 & $25.4^{\mathrm{b}}$ & 1.43 & 2.003 & 0.201 \\
\hline$P$-value & 0.892 & 0.043 & 0.339 & 0.151 & 0.940 \\
\hline \multicolumn{6}{|c|}{ Duration of feeding diets with WPC } \\
\hline $1-7$ days & 76.9 & $24.0^{\mathrm{a}}$ & 1.54 & 2.070 & $0.185^{\mathrm{a}}$ \\
\hline $1-21$ days & 77.3 & $24.8^{\mathrm{a}}$ & 1.37 & 2.044 & $0.198^{\mathrm{ab}}$ \\
\hline $1-42$ days & 77.7 & $26.1^{\text {b }}$ & 1.56 & 2.015 & $0.218^{b}$ \\
\hline$P$-value & 0.195 & $<0.001$ & 0.309 & 0.711 & 0.031 \\
\hline \multicolumn{6}{|l|}{ Sex of chickens } \\
\hline males & 77.0 & $24.4^{\mathrm{a}}$ & $1.27^{\mathrm{a}}$ & 1.998 & 0.202 \\
\hline females & 77.6 & $25.6^{\mathrm{b}}$ & $1.71^{\mathrm{b}}$ & 2.088 & 0.198 \\
\hline$P$-value & 0.104 & 0.006 & $<0.001$ & 0.103 & 0.721 \\
\hline \multicolumn{6}{|l|}{ Interactions (P-value) } \\
\hline level $\times$ duration & 0.746 & 0.214 & 0.214 & 0.127 & 0.793 \\
\hline level $\times$ sex & 0.358 & 0.172 & 0.227 & 0.943 & 0.951 \\
\hline duration $\times$ sex & 0.301 & 0.736 & 0.445 & 0.240 & 0.159 \\
\hline level $\times$ duration $\times$ sex & 0.404 & 0.510 & 0.425 & 0.559 & 0.182 \\
\hline \multicolumn{6}{|l|}{ Contrasts $^{4}$} \\
\hline C1 =1 vs $2+3+4$ & $* *$ & ns & ns & ns & ns \\
\hline$C 2=1$ vs $5+6+7$ & $* *$ & $*$ & ns & ns & ns \\
\hline $\mathrm{C} 3=1$ vs 2 & ns & ns & ns & ns & ns \\
\hline $\mathrm{C} 4=1 \mathrm{vs} 3$ & $*$ & ns & ns & ns & ns \\
\hline$C 5=1$ vs 5 & ns & ns & ns & ns & ns \\
\hline $\mathrm{C} 6=1$ vs 6 & $*$ & $*$ & ns & ns & ns \\
\hline$C 7=2$ vs 5 & ns & ns & ns & ns & ns \\
\hline$C 8=3$ vs 6 & ns & $*$ & ns & ns & ns \\
\hline $\mathrm{C} 9=4$ vs 7 & ns & ns & ns & ns & ns \\
\hline
\end{tabular}

${ }^{1}$ for abbreviations - see Table $2 ;{ }^{2}$ LBW - live body weight; ${ }^{3}$ for main effects, values within a column with different letters are significantly different at $P<0.05 ;{ }^{4}$ for contrasts significance - see Table 3

\section{Blood characteristics}

Differences between the total leukocyte counts were not significant, with a tendency to be numerically lower in broilers receiving $32 \mathrm{~g}$ WPC per kg of diet than for those control feed (Table 5). The relative lymphocyte count ( $\%$ of total WBC) did not 
Table 5. Effect of WPC dietary level $\left(\mathrm{g} \cdot \mathrm{kg}^{-1}\right)$ on the blood indices and 2-thiobarbituric acid reactive substances (TBARS) in the liver and breast meat of chickens, the $\mathrm{pH}$ of caecal contents and small intestinal digesta, weight of the small intestine ${ }^{1}$, and ileal digestibility of crude protein (CP) in basal grower diet without WPC, after termination of 3-week period of feeding diets with WPC

\begin{tabular}{|c|c|c|c|c|c|c|}
\hline \multirow{2}{*}{ Indices } & \multirow{2}{*}{ Age $^{2}$} & \multicolumn{3}{|l|}{ Diets } & \multirow{2}{*}{ SEM } & \multirow{2}{*}{$P$-value } \\
\hline & & control & 8 WPC & 32 WPC & & \\
\hline \multicolumn{7}{|l|}{ Blood indices } \\
\hline \multirow[t]{2}{*}{ leukocytes (WBC), $10^{9} \cdot \mathrm{H}^{-1}$} & 21 & 23.50 & 21.95 & 21.87 & 0.41 & 0.188 \\
\hline & 42 & 25.16 & 23.98 & 21.68 & 0.46 & 0.276 \\
\hline \multirow[t]{2}{*}{ lymphocytes ${ }^{3}(\mathrm{~L}), \%$} & 21 & 59.83 & 61.08 & 61.50 & 1.01 & 0.118 \\
\hline & 42 & $60.87^{a}$ & $61.30^{\mathrm{ab}}$ & $63.25^{\mathrm{b}}$ & 0.47 & 0.061 \\
\hline \multirow[t]{2}{*}{ heterophiles ${ }^{3}(\mathrm{H}), \%$} & 21 & 31.68 & 31.22 & 30.05 & 0.48 & 0.338 \\
\hline & 42 & 33.52 & 31.83 & 31.17 & 0.51 & 0.156 \\
\hline \multirow[t]{2}{*}{$\mathrm{H} / \mathrm{L}$ ratio } & 21 & 0.53 & 0.51 & 0.49 & 0.01 & 0.433 \\
\hline & 42 & $0.55^{\mathrm{a}}$ & $0.52^{\mathrm{ab}}$ & $0.49^{b}$ & 0.01 & 0.062 \\
\hline \multirow[t]{2}{*}{ erythrocytes (RBC), $10^{12} \cdot \mathrm{I}^{-1}$} & 21 & 1.91 & 2.12 & 2.10 & 0.04 & 0.198 \\
\hline & 42 & $2.40^{\mathrm{a}}$ & $2.55^{\mathrm{ab}}$ & $2.73^{b}$ & 0.05 & 0.015 \\
\hline \multirow[t]{2}{*}{ haemoglobin, $\mathrm{mmol} \cdot \mathrm{I}^{-1}$} & 21 & 5.36 & 6.01 & 6.06 & 0.15 & 0.114 \\
\hline & 42 & 5.84 & 6.02 & 6.05 & 0.11 & 0.732 \\
\hline \multirow[t]{2}{*}{ haematocrit, $|\cdot|^{-1}$} & 21 & 0.248 & 0.278 & 0.283 & 0.01 & 0.131 \\
\hline & 42 & 0.323 & 0.335 & 0.350 & 0.01 & 0.203 \\
\hline \multirow[t]{2}{*}{ total protein, $\mathrm{g} \cdot \mathrm{I}^{-1}$} & 21 & $26.70^{a}$ & $30.17^{b}$ & $30.70^{\mathrm{b}}$ & 0.60 & 0.005 \\
\hline & 42 & 34.22 & 34.90 & 35.18 & 0.47 & 0.734 \\
\hline \multirow[t]{2}{*}{ glucose, $\mathrm{mmol} \cdot \mathrm{l}^{-1}$} & 21 & $13.02^{\mathrm{a}}$ & $13.15^{\mathrm{a}}$ & $15.19^{b}$ & 0.36 & 0.017 \\
\hline & 42 & 13.71 & 13.87 & 14.22 & 0.20 & 0.195 \\
\hline \multicolumn{7}{|l|}{ TBARS values, mg MDA $\cdot \mathrm{kg}^{-1}$} \\
\hline \multirow{2}{*}{ liver $^{4}$} & 21 & 0.784 & 0.755 & 0.728 & 0.01 & 0.148 \\
\hline & 42 & $0.863^{\mathrm{a}}$ & $0.842^{\mathrm{ab}}$ & $0.807^{b}$ & 0.01 & 0.028 \\
\hline breast meat ${ }^{5}$ & 43 & 0.367 & 0.354 & 0.326 & 0.01 & 0.107 \\
\hline \multirow[t]{2}{*}{ Caecal pH } & 21 & 6.43 & 6.28 & 6.11 & 0.10 & 0.476 \\
\hline & 42 & $6.29^{a}$ & $6.25^{\mathrm{ab}}$ & $5.78^{b}$ & 0.10 & 0.022 \\
\hline \multirow[t]{2}{*}{ Intestinal pH } & 21 & 5.64 & 5.49 & 5.28 & 0.10 & 0.377 \\
\hline & 42 & $5.54^{\mathrm{a}}$ & $5.33^{\mathrm{ab}}$ & $5.03^{b}$ & 0.08 & 0.065 \\
\hline \multirow[t]{2}{*}{ Small intestine, g per $100 \mathrm{~g} \mathrm{LBW}$} & 21 & 3.23 & 3.30 & 3.53 & 0.14 & 0.713 \\
\hline & 42 & $2.36^{\mathrm{a}}$ & $2.44^{\mathrm{ab}}$ & $2.76^{b}$ & 0.08 & 0.078 \\
\hline Ileal CP digestibility & 26 & $0.793^{\mathrm{a}}$ & $0.805^{\mathrm{a}}$ & $0.851^{\mathrm{b}}$ & 0.01 & $<0.001$ \\
\hline
\end{tabular}

${ }^{1}$ small intestine = duodenum + jejunum + ileum; ${ }^{2}$ day of sampling; ${ }^{3}$ values presented as percentage of total WBC count; ${ }^{4}$ fresh tissue, for day 42 of age total $n=18 ;{ }^{5}$ after 3 -month storage at $-20^{\circ} \mathrm{C}$; values within a row with different letters are significantly different at $P<0.05$

significantly differ among treatments on sampling day 21. On day 42, however, birds fed the diet containing $32 \mathrm{~g} \cdot \mathrm{kg}^{-1}$ WPC had a higher lymphocyte percentage $(P<0.05)$ compared with those fed the control diet. On the other hand, WPC added to the diets had little influence on the relative heterophile counts on both days 21 and 42. Consequently, only long-term (42 days) feeding of diets with $32 \mathrm{~g}$. $\mathrm{kg}^{-1}$ of WPC significantly affected the $\mathrm{H} / \mathrm{L}$ ratio, which was lower than that for the control diets. The number of RBC on day 21 was unaffected by WPC level. In birds fed $32 \mathrm{~g}$ WPC diets during the entire experiment, however, the RBC count was higher $(P<0.05)$ than in controls. The haemoglobin and haematocrit concentrations tended to be numerically higher in $32 \mathrm{~g}$ WPC-fed birds than in controls, but there were no significant differences for these parameters on both sampling days. The concentration of total protein in serum of blood collected on day 21 was greater $(P<0.05)$ for WPC-fed birds compared with the control group of chickens, but remained unaffected by WPC dietary levels on day 42 . The $32 \mathrm{~g} \cdot \mathrm{kg}^{-1}$ WPC group had a higher $(P<0.05)$ glucose content of whole blood drawn after 21 days of treatment compared with the other two groups, but in 6-week-old broilers such an effect was not statistically confirmed.

\section{TBARS values}

The effect of WPC on the TBARS value in fresh liver tissue analysed 21 days after initiation of feeding was not statistically significant (Table 5), however, a tendency towards numerically lower TBARS values than the control level was noted in the $32 \mathrm{~g} \cdot \mathrm{kg}^{-1}$ WPC treatment group. A significant reduction in the liver TBARS value (by $6.5 \%$ ) was observed on the $32 \mathrm{~g}$ WPC diets when fed until the end of the experiment (day 42; $P<0.05$ ). A similar tendency towards a decline in TBARS level (32 $\mathrm{g} \mathrm{WPC} / \mathrm{kg}$ feed $<$ control feed) was found for breast meat after frozen storage for 3 months. 


\section{Intestinal tract parameters}

After 3 weeks of feeding, the response of chickens in terms of $\mathrm{pH}$ of caecal contents and digesta from the whole small intestinal tract, and small intestine weight to dietary WPC was not statistically significant (Table 5). The birds fed diets (prestarter + starter) containing $32 \mathrm{~g}$ WPC per $\mathrm{kg}$, however, had the numerically lowest $\mathrm{pH}$ in the caeca and in the small intestine, and the greatest relative intestinal weight among the evaluated groups, followed by birds given the $8 \mathrm{~g}$ WPC and control diets, respectively. At day 42, the above relationships were statistically confirmed $(P<0.05)$ for caecal and intestinal $\mathrm{pH}$ and intestinal relative weight in chickens fed diets containing $32 \mathrm{~g}$ WPC per kg compared with the control birds.

The AIDCP in the basal grower diet determined on day 26 of age was significantly greater $(P<0.01)$ in birds provided with $32 \mathrm{~g}$ WPC during the first 21 days of life compared with birds fed the $8 \mathrm{~g}$ WPC (on the same schedule) or control diets (Table 5). Interestingly, although not significant, a somewhat better AIDCP (higher than control value) was observed in broilers after 3 weeks feeding with $8 \mathrm{~g}$ $\mathrm{WPC} \cdot \mathrm{kg}^{-1}$ diet.

\section{Discussion}

In view of biological properties and metabolic functions of WP, it was not unreasonable to anticipate that the dietary inclusion of WPC would result in improved productivity of broilers over those fed on the control (basal) diets. Indeed, in the current experiment, treatment with 8 and $32 \mathrm{~g} \cdot \mathrm{kg}^{-1}$ WPC for at least 21 days increased the BWG of chickens, despite their similar or lower feed intakes, compared with the birds in the control group. Consequently, chickens offered WPC in consecutive feeding phases had better FCR than controls, with approximately the same extent of improvement for both dietary WPC levels. These effects somewhat resemble those reported by Awano (2004), who found that the dietary presence of WPC counteracts the decrease of feed efficiency in broilers when fed diets burdened with added oxidized soyabean oil. Moreover, authors, who investigated supplementation of diets by dried whey, found BWG to be greater for chickens offered this product in amounts equivalent to a WP level between $3-6 \mathrm{~g} \cdot \mathrm{kg}^{-1}$ (Gulsen et al., 2002; Kermanshahi and Rostami, 2006).

Although we cannot exclude that in WPC-diets the higher supply level of some indispensable amino acids (e.g., Thr, Leu, Ile, Val) was partially involved in the improvement of chicken growth, it is worth noting that in all of the same type diets the concentrations of lysine, which is used almost exclusively for muscle protein synthesis, were similar. The present results indicate that the improvement in growth rate of WPC-fed birds occurred likely primarily due to better nutrient digestibility and/or the capacity of the intestines to absorb nutrients. We found that ileal digestibility of crude protein in the basal diet was already higher after a 21-day pretreatment period of feeding WPC, with a striking difference at the level of $32 \mathrm{~g} \cdot \mathrm{kg}^{-1}$, which supports the above conjecture. Furthermore, we noted an enhancing effect of adding WPC to the diets on intestinal weight expressed per unit of body mass. Although the histological structure of the small intestine was not determined in this study, it is possible that this enhancement corresponded to better development of the intestinal mucosa under the abundance of intestinotrophic hormone glucagon-like peptide 2 (GLP-2). During their studies with parenterally fed rodent models, Liu et al. (2009) revealed that whey protein increases the action of GLP-2, showing an ability to induce higher cell density and greater absorptive surface area. It is noteworthy that GLP-2 administered to chickens via injection has been shown to increase the relative intestinal weight, villus height, expression of nutrient transporter mRNA (including $\mathrm{Na}+/$ glucose co-transporter-1 and peptide transporter-1 mRNA) in the small intestine, and, consequently, growth performance (Hu et al., 2010). Thus, it can be hypothesized that in the current experiment, increased integrity of the intestinal tract associated with a greater villi height and surface area after WPC supplementation resulted in improved live performance and carcass indices of broilers. Although we can only speculate on the upregulation of nutrient transporter mRNA, our study produced some physiological evidence for enhanced transcellular transport of glucose and peptide-bound amino acids from the intestine into the blood of WPC-fed birds. Results for whole blood glucose and serum total protein appear to indirectly support this assertion.

Conceivably, the above effects could also be attributed to the action of lactose contained in WPC. An increase in intestinal villi length in lactosetreated broilers during the starter period, which was assumed to improve nutrient absorption and bird performance, was reported by Gulsen et al. (2002). Also, investigations on the prebiotic properties of some oligosaccharides, FOS as an example (Xu et al., 2003), showed a very similar effect to the aforementioned on the jejunal and ileal tissues of chickens, along with higher digestive enzyme activities in the small intestinal contents. It was concluded 
that this phenomenon is likely related to the ability of the added prebiotic to create a more favourable intestinal environment for useful microbiota.

In our study, in addition to the general superiority of the WPC-containing diets over the control ones in terms of chicken performance, we found a strong positive relation between prolonged duration of WPC feeding and outcome in final BWG and breast meat yield, especially for the $32 \mathrm{~g} \cdot \mathrm{kg}^{-1} \mathrm{WPC}$ dietary level. On the other hand, the BWG of chickens during days $22-42$, and both BWG and FCR at the end of rearing period were significantly affected by WPC levels fed only for the first 3 weeks of life. This response may perhaps be explained by the carry-over effects following the short-term feeding with WPC-fortified diets on intestinal integrity and functionality embodying desirable changes in mucosa morphology and microbial ecosystem, which were reflected in better subsequent performance.

In the current experiment, the amounts of lactose resulting from the application of WPC were 0.47 and $1.88 \mathrm{~g} \cdot \mathrm{kg}^{-1}$ diet, respectively. Considering that a range of chicken intestinal microbiota, predominantly species of the lactic acid bacteria (LAB) and the coliform bacillus groups, are able to ferment lactose with the production of short-chain organic acids, reduced $\mathrm{pH}$ of caecal contents in WPC-fed birds was expected. We found, however, that this effect was apparent only for the 42-day period of feeding with $32 \mathrm{~g} \cdot \mathrm{kg}^{-1}$ WPC (1.88 $\mathrm{g} \cdot \mathrm{kg}^{-1}$ lactose). Similarly, Józefiak et al. (2008) observed that the addition of $2 \mathrm{~g} \cdot \mathrm{kg}^{-1}$ lactose to the basal diet significantly decreased caecal $\mathrm{pH}$ in the sixth week of a chicken's life. The significant response to the WPC level providing $1.88 \mathrm{~g} \cdot \mathrm{kg}^{-1}$ lactose in terms of reduced $\mathrm{pH}$ of digesta from the whole small intestinal tract is most likely associated with fermentation in the ileum. Inconsistent effects of adding different prebiotic carbohydrates, including lactose, on the upper intestinal tract $\mathrm{pH}$, and bacterial populations, have been noted in poultry, however. Some previous reports demonstrated that ileum $\mathrm{pH}$ in chickens was not significantly affected by either low $(0.2 \%)$ or high $(4.5 \%)$ dietary lactose levels, with lower LAB counts (Józefiak et al., 2008) or with no effect on the counts of Escherichia coli, enterococci and lactobacilli (McReynolds et al., 2007). In contrast, Samli et al. (2007) claimed that treatment with dried whey, in an amount equivalent to $28 \mathrm{~g} \cdot \mathrm{kg}^{-1}$ lactose, significantly increases the total number of LAB in the ileum of chickens. Although not measured in the above study, this would suggest a lower $\mathrm{pH}$ of the ileal digesta. On the other hand, results of recent studies on the effects of using $0.5 \mathrm{~g} \cdot \mathrm{kg}^{-1}$
MOS (Khalaji et al., 2011) or $1 \mathrm{~g} \cdot \mathrm{kg}^{-1}$ inulin (Abdelqader et al., 2013) in the diets for broilers and laying hens have shown that these supplements significantly lowered the ileal $\mathrm{pH}$ or modulated ileal microflora by increasing numbers of bifidobacteria and lactobacilli.

Determination of the development of lymphoid organs (e.g., spleen) based on their weight measurement, along with calculating the blood heterophileto-lymphocyte ratio, are common methods for assessment of immune system function and symptoms of immunity-related physiological stress in broiler chickens. The ameliorated relative weight of immune organs and/or higher lymphocyte production (declined $\mathrm{H} / \mathrm{L}$ ratio) can, to some extent, suggest better immunity of the birds. The results from our experiment showed an increasing trend in relative spleen weight coupled with the prolonged duration of WPC feeding. We also found an elevated relative lymphocyte count, and thus, lower $\mathrm{H} / \mathrm{L}$ ratio for 6-week dietary treatment with $32 \mathrm{~g} \cdot \mathrm{kg}^{-1} \mathrm{WPC}$. Both of these observations may reflect the better immune status of chickens from the 32WPC_42 group. Several in vitro studies involving murine material have demonstrated immunomodulatory effects of bovine WP preparations on splenic lymphocyte clonal expansion and function. Wong et al. (1998) provided evidence that a WP mixture can significantly increase cell expansion and production of $\operatorname{IgM}$ by splenocytes. Mercier et al. (2004) found whey protein from isolates to significantly induce proliferation of splenic lymphocytes without mitogen stimulation. Brix et al. (2003) reported that a commercial $\beta$-lactoglobulin preparation significantly increased proliferation of spleen lymph nodes and stimulated the cellular glutathione concentration in spleen cell cultures.

It is of importance to inhibit oxidative damage caused by reactive oxygen species (referred to as 'oxidative stress') in living cells. Reduced glutathione (GSH) is the most important cellular antioxidant, and its strong radical scavenging activity is critical in maintaining cellular redox status (Shoveller et al., 2005). Studies with rats, mice and chickens indicate that it is possible to obtain considerable elevation of GSH levels in liver, heart and RBCs by the administration of bovine WP preparations (Bounous et al., 1989; Zommara et al., 1998; Awano, 2004). In this study, the dietary supply of WPC in the amount of $32 \mathrm{~g} \cdot \mathrm{kg}^{-1}$ over a period of 42 days significantly lowered the TBARS value for fresh liver tissue, measured as the MDA level. This is similar to the report of Zommara et al. (1998) demonstrating decreased TBARS concentrations in the liver of 
rats fed a diet with WP products. Additionally, in $32 \mathrm{~g} \cdot \mathrm{kg}^{-1}$ WPC-treated birds we found a rise in the blood RBC count $(P<0.05)$, with a general upturn in haemoglobin and haematocrit levels as compared with controls. The reason for the former response may be related to the inhibition of RBC haemolysis. Such inhibition has been shown by Zommara et al. (1998) in rats fed diets supplemented with WP isolate or whey product containing $383 \mathrm{~g} \cdot \mathrm{kg}^{-1}$ of protein. The above effect could be associated with antioxidative protection of the RBCs by lactoferrin, which is capable of binding metal ions and, thus, blocking their catalytic participation in membrane damage (Maneva et al., 2003). It can be deduced that the better antioxidant status in the living body of broilers fed $32 \mathrm{~g} \cdot \mathrm{kg}^{-1}$ WPC for 42 days, and thus lower propagation of the radical-mediated peroxidation reaction, was the most probable reason for the tendency towards reduced MDA formation in long-term frozen stored breast meat in this study.

\section{Conclusions}

In conclusion, our results show that feeding whey protein concentrate (WPC) with approximately $800 \mathrm{~g} \cdot \mathrm{kg}^{-1}$ protein and $59 \mathrm{~g} \cdot \mathrm{kg}^{-1}$ lactose contents can be regarded as a method for elevating production efficiency and meat yield in broiler chickens. Amongst the two dietary levels applied in this experiment $\left(8\right.$ or $\left.32 \mathrm{~g} \cdot \mathrm{kg}^{-1}\right)$, the results suggest that performance - and potentially health-related benefits - may be most apparent when $32 \mathrm{~g} \cdot \mathrm{kg}^{-1}$ is added. At this dietary level, WPC fed for 21 days improved the ileal digestibility of crude protein, WPC fed for 42 days lowered both caecal and intestinal $\mathrm{pH}$, increased the relative weight of the small intestine, and lowered the extent of oxidative processes involved with malondialdehyde formation in the liver and frozen-stored breast meat. It has been shown that advantageous performance responses at day 42 of life can be obtained by feeding WPC supplements solely through the first 21-day period. We suggest that WPC can be used as a potential growth promoter, however, additional production costs resulting from dietary inclusion of WPC should be considered.

\section{Acknowledgements}

This work was conducted as part of National Research Institute of Animal Production statutory activity, Project No. 2257.1.

\section{References}

Abdelqader A., Al-Fataftah A.R., Gurbuz D., 2013. Effects of dietary Bacillus subtilis and inulin supplementation on performance, eggshell quality, intestinal morphology and microflora composition of laying hens in the late phase of production. Anim. Feed Sci. Tech. 179, 103-111

AOAC, 2000. Association of Official Analytical Chemists, Official Methods of Analysis. $17^{\text {th }}$ Edition. Gaithersburg, MD

Atkinson R.L., Kratzer F.H., Stewar.G.F., 1957 (cited in Rehman et al., 2009). Lactose in animal and human feeding: a review. J. Dairy Sci. 40, 114-132

Awano T., 2004. The effect of whey protein on growth performance, lipid metabolism and blood and liver glutathione in broilers fed oxidized soy bean oil. 22 ${ }^{\text {nd }}$ World's Poultry Congress. Istanbul (Turkey), Book of Abstracts, p. 672 (CD full text, pp. 4)

Bounous G., Gervais F., Amer V., Batist G., Gold P., 1989. The influence of dietary whey protein on tissue glutathione and the diseases of aging. Clin. Invest. Med. 12, 343-349

Brix S., Bovetto L., Fritsche R., Barkholt V., Frokiaer H., 2003. Immunostimulatory potential of beta-lactoglobulin preparations: effects caused by endotoxin contamination. J. Allergy Clin. Immunol. 112, 1216-1222

Brodziak A., Barłowska J., Król J., Litwińczuk Z., 2012. Effect of breed and feeding system on content of selected whey proteins in cow's milk in spring-summer and autumn-winter seasons. Ann. Anim. Sci. 12, 261-269

Douglas M.W., Persia M., Parsons C.M., 2003. Impact of galactose, lactose and Grobiotic-B70 on growth performance and energy utilization when fed to broiler chicks. Poultry Sci. 82, 1596-1601

Gulsen N., Coskun B., Umucalilar H.D., Inal F., Boydak M., 2002. Effect of lactose and dried whey supplementation on growth performance and histology of the immune system in broilers. Arch. Anim. Nutr. 56, 131-139

Hu X.F., Guo Y.M., Huang B.Y., 2010. The effect of glucagon-like peptide 2 injection on performance, small intestinal morphology, and nutrient transporter expression of stressed broiler chickens. Poultry Sci. 89, 1967-1974

Józefiak D., Kaczmarek S., Rutkowski A., 2008. A note on the effects of selected prebiotics on the performance and ileal microbiota of broiler chickens. J. Anim. Feed Sci. 17, 392-397

Kermanshahi H., Rostami H., 2006. Influence of supplemental dried whey on broiler performance and cecal flora. Int. J. Poultry Sci. 5, 538-543

Khalaji S., Zaghari M., Hatami K., Hedari-Dastjerdi S., Lotfi L., Nazarian H., 2011. Black cumin seeds, Artemisia leaves (Artemisia sieberi), and Camellia L. plant extract as phytogenic products in broiler diets and their effects on performance, blood constituents, immunity, and cecal microbial population. Poultry Sci. 90, 2500-2510

Lentner M., Bishop T., 1993. Experimental Design and Analysis. $2^{\text {nd }}$ Edition. Valley Book Co., Blacksburg, VA, pp. 585

Liu X., Murali S.G., Holst J.J., Ney D.M., 2009. Whey protein potentiates the intestinotrophic action of glucagon-like peptide-2 in parenterally fed rats. Amer. J. Physiol. Regul. Integr. C. 297, 554-562

Madureira A.R., Pereira C.I., Gomes A.M.P., Pintado M.E., Malcata F.X., 2007. Bovine whey proteins - overview on their main biological properties. Food Res. Int. 40, 1197-1211

Maneva A., Taleva B., Maneva L., 2003. Lactoferrin - protector against oxidative stress and regulator of glycolysis in human erythrocytes. Z. Naturforsch. 58c, 256-262

McReynolds J.L., Byrd J.A., Genovese K.J., Poole T.L., Duke S.E., Farnell M.B., Nisbet D.J., 2007. Dietary lactose and its effect 
on the disease condition of necrotic enteritis. Poultry Sci. 86 , 1656-1661

Mercier A., Gauthier S.F., Fliss I., 2004. Immunomodulating effects of whey proteins and their enzymatic digests. Int. Dairy J. 14, 175-183

Pikul J., Dennis E. Leszczynski D.E., Kummerow F.A., 1989. Evaluation of three modified TBA methods for measuring lipid oxidation in chicken meat. J. Agr. Food Chem. 37, 1309-1313

Rehman H., Vahjen W., Kohl-Parisini A., ljaz A., Zentek J., 2009. Influence of fermentable carbohydrates on the intestinal bacteria and enteropathogens in broilers. World Poultry Sci. J. 65, 75-90

Saha D.C., Gilbreath R.L., 1991. Analytical recovery of chromium from diet and feces determined by colorimetry and atomic absorption spectrophotometry. J. Sci. Food Agr. 55, 433-446

Samli H.E., Senkoylu N., Koc F., Kanter M., Agma A., 2007. Effects of Enterococcus faecium and dried whey on broiler performance, gut histomorphology and intestinal microbiota. Arch. Anim. Nutr. 61, 42-49
Shoveller A.K., Stoll B., Ball R.O., Burrin D.G., 2005. Nutritional and functional importance of intestinal sulfur amino acid metabolism. J. Nutr. 135, 1609-1612

Tellez G., Dean C.E., Corrier D.E., Deloach J.R., Jaeger L., Hargis B.M., 1993. Effect of dietary lactose on cecal morphology, $\mathrm{pH}$, organic acids and Salmonella enteritidis organ invasion in leghorn chicks. Poultry Sci. 72, 636-642

Wong K.F., Middleton N., Montgomery M., Dey M., Carr R.I., 1998. Immunostimulation of murine spleen cells by materials associated with bovine milk protein fractions. J. Dairy Sci. 81, 1825-1832

Xu, Z.R., Hu C.H., Xia M.S., Zhan X.A., Wang M.Q., 2003. Effects of dietary fructooligosaccharide on digestive enzyme activities, intestinal microflora and morphology of male broilers. Poultry Sci. 82, 1030-1036

Zommara M., Toubo H., Sakono M., Imaizumi K., 1998. Prevention of peroxidative stress in rats fed on a low vitamin E-containing diet by supplementing with a fermented bovine milk whey preparation: effect of lactic acid and $\beta$-lactoglobulin on the antiperoxidative action. Biosci. Biotechnol. Biochem. 62, 710-717 